
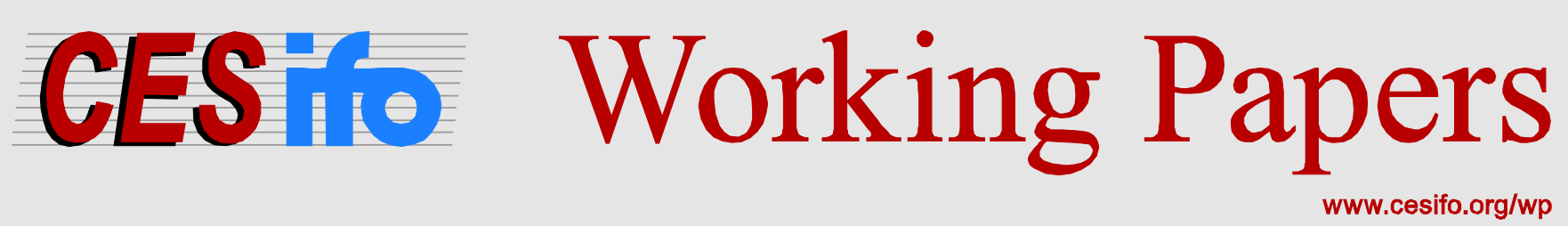

\title{
Climate Change, Rice Crops and Violence. Evidence from Indonesia
}

\author{
Raul Caruso \\ Ilaria Petrarca \\ Roberto Ricciuti
}

\author{
CESIFO WORKING PAPER NO. 4665 \\ CATEGORY 10: ENERGY AND ClimATE ECONOMICS \\ FEBRUARY 2014
}

An electronic version of the paper may be downloaded

- from the SSRN website:

- from the RePEc website:

- from the CESifo website:

WWW.SSRN.com

www.RePEc.org

www.CESifo-group.org/wp

\section{CESifo}




\title{
Climate Change, Rice Crops and Violence. Evidence from Indonesia
}

\begin{abstract}
This paper adopts an instrumental variable approach to uncover the impact of variations in minimum temperature on emergence and severity of actual violence through the effect on food availability, captured by rice crops per capita. The link between increase in minimum temperature and rice crops is suggested by natural science literature. We use Indonesia as a case study over the period 1990-2003. Results show that an increase of the minimum temperature during the core month of the 'wet planting season', i.e. December, determines an increase in violence fuelled by the reduction in future rice production per capita.
\end{abstract}

JEL-Code: D740, Q540, O130.

Keywords: Indonesia, climate change, minimum temperature, rainfall, food availability, paddy rice, rice crops, routine violence.

Raul Caruso*
Center for Applied Economics (CSEA)
Via Necchi 5
Italy-20123 Milan
raul.caruso@unicatt.it

Roberto Ricciuti

University of Verona

Verona / Italy

roberto.ricciuti@univr.it

*corresponding author

November 19, 2013

Earlier drafts of this paper have been presented at: the 13th Jan Tinbergen European Peace Science Conference, June 24-26 2013, Milan, the Post-doctoral seminars at the University of Verona, the II Workshop on the Political Economy of Conflict organized by EPS-Italy and CSEA at the Catholic University of the Sacred Heart in Milan, and the University of Manchester. We warmly thank the participants who commented on this work. In particular, we also thank Syed Mansoob Murshed for providing us with data on poverty in Indonesia. Roberto Ricciuti thanks Nuffield College for hospitality under the Jemolo Fellowship. We also acknowledge financial support from the University of Verona. 


\section{Introduction}

The impact of climate change on emergence and recrudescence of violent conflicts has become one of the more lively debates in the latest years. However, despite the substantial number of studies, results are puzzled, contradictory and somehow inconclusive (see Buhaug et al., and 2013Hsiang et al., 2013). In brief, on the basis of the existing studies, scholars are not able to espouse a general interpretation of the climate change/violence nexus. ${ }^{1}$

Several aspects contribute to the inconclusiveness of the literature. First, as pointed out by Theisen et al. (2013), the causal mechanism behind the climate change/violence relationship may vary across societies, regions and territories. In the eyes of economists, climate change results into exogenous shocks that significantly affect agricultural production so shaping the set of economic opportunities, and thereby the incentives and opportunity cost of individuals. Needless to say, characteristics of agricultural sectors differ significantly among countries, regions and territories so shaping any potential relationship between agricultural shocks induced by climate change and actual conflict.

Secondly, measures of climate change differ and therefore results of empirical studies can lead to different interpretations. Among social scientists, climate change has been frequently approximated in the literature on conflict by means of variations in rainfall and mean temperature. In particular, since Miguel et al. (2004), rainfall has been the core variable of interest to explain the relationship between conflict and climatic variations. The explanation grounds on the idea that substantial negative variations of rainfall induce drought so raising the risk of conflict. Ciccone (2011) challenges the previous results so stating that rainfall is unrelated to conflict. ${ }^{2}$ Burke at al. (2009) had shifted the focus on the temperature so predicting that warming can be considered a strong predictor of civil war in Africa, but Buhaug (2010) showed that the results are not robust if using alternative specification. Briefly stated, alternative measures and specifications of the climatic variables contribute to make the results puzzled and inconclusive. This

\footnotetext{
1 The literature on the nexus between climate change and violence increased dramatically in the latest years. See among others Gleditsch (2012), Hendrix and Salehyan (2012), Fjelde and Uexkull (2012), Koubi et al. (2012), Slettebak (2012), Scheffran et al. (2012), Raleigh et al. (2008), Raleigh and Urdal, (2013).

2 See also Miguel and Satyanath (2011) that replies to criticism proposed by Ciccone (2011).
} 
poses well-grounded doubts on the universal application of a predictable causal from path climate change to violence.

Moreover, actual violence takes several shapes and it can be either influenced or inflamed differently by climatic variables. Actors of civil wars can be expected to react differently from individuals involved in unorganized rioting, routine violence and other types of spontaneous societal unrest. Eventually, the role played by other societal factors as the level of development or the institutional architecture can be expected to be substantial. Consequently, it must not be surprising that studies focusing on large panels of countries present inconclusive and puzzled results. In particular, as noted by Bernauer et al. (2012), drawing general proposition from large- $\mathrm{N}$ studies is not appropriate because most of them are not robust to alternative specifications.

In the light of the previous points, we have chosen to bound our study to a single country with a dominant crop and a substantial history of violence. Then, we focus on Indonesia for the period 1990-2003. The choice is well-grounded: the country is a case study that does fit particularly well into such approach.

First, Indonesia has a well-studied history of violence. In particular, Tadjoeddin and Murshed (2007) explain the emergence of routine violence by pointing out the economic factors associated with everyday violence in Java. The escalation of violence, in particular, has been accompanied by the three transitions at the end of the 1990s (Tadjoeddin, 2002): (i) political (from autocracy to democracy), (ii) economic (from crony capitalism to ruled-based market system) and (iii) social (centralized-decentralized). The overall severity of conflict peaked after the fall of Suharto's regime in 1998 and decreased after 2001. Reduction of violence can be explained in the light of: (1) fiscal decentralization. (Murshed and Tadjoeddin, 2008); repression against terrorism in the aftermath of Bali bombing in 2002; the end of the long lasting separatist war in Aceh. However, despite the decreasing pattern of conflict severity, the number of violent incidents has risen after 2002 (World Bank Conflict and Development Program, 2010).

The second facet taken into account is that the Indonesian economy is heavily dependent on rice crops. According to the figures drawn from FAO dataset, ${ }^{3}$ rice is the main crop in terms of both quantity and value as well as the top commodity

\footnotetext{
${ }^{3}$ See $h$ ttp: / / faostat.fao.org / CountryProfiles /Country_Profile / Direct.aspx?lang=en\&area=101
} 
available for internal consumption. In this respect, it is necessary to note that in spite of being a top rice-producer in the world, Indonesia has historically been a net importer of rice (McCulloch, 2008). ${ }^{4}$ Food availability heavily depends on rice crops, and more than one fifth of the population is involved in agricultural production. Then, it is not surprising that climate change has been already studied with regard to agricultural production and food availability (see among others Naylor et al. 2001; Naylor et al. 2007; Keil et al., 2008; Skoufias et al., 2012).

Then, we investigate the impact of climate change on violence by exploring the causal mechanism of agricultural production. In particular, we analyze the impact of climate change on rice crops and eventually on emergence of violence. We test this hypothesis by exploiting a newly assembled provincial dataset that matches the data provided by the United Nations Support Facility for Indonesian Recovery $^{5}$ (hereafter UNSFIR) with climatic data and a set of socio-economic controls over the period 1990-2003.

The main novelty we claim for this work is that drawing insights from the natural science literature, we use variations in minimum temperature rather than average temperature. Such choice drives significant results, therefore strengthening the idea that climate change inflames violence.

In sum, the results show, consistently with our hypothesis, that an increase of the minimum temperature during the core month of the 'wet planting season', i.e., December, determines an increase in violence fuelled by the reduction in future rice production. Therefore, we find support for the hypothesis that minimum temperature negatively affects rice availability (per capita), which in turn inflames violence. This evidence is robust to alternative specifications of the dependent variable, as well as the inclusion of a number of controls. In particular, we study two measures of violence, namely the emergence of violence proxied by number of monthly events, and the severity of violence proxied by means of the number of monthly victims (sum of injured and killed people). Unfortunately, this work has limitations due to the number of observations available and the lack of data. However, we consider the results robust enough to provide new evidence on the relationship between climate variables and variables in Indonesia and to warrant

\footnotetext{
${ }^{4}$ Indonesia is considered the third top producer in the world. In 2011 the quantity of rice production was 65,741 thousands of tons but the quantity exported was 0.8 thousand of tons.

${ }^{5}$ For a description of the dataset see Varshney et al. (2004).
} 
further explorations for different countries and crop/temperature bundles. Another result we claim for this work is methodological. We believe that the robust evidence descends from taking into account the agricultural specificities of paddy rice. Stated broadly, our work cautiously suggests that some inconclusive results in literature on the climate change/violence nexus could suffer from not considering heterogeneity and specific characteristics of different crops.

The rest of the paper develops as follows. Section 2 illustrates from the perspective of the natural science the relationship between minimum temperature and violence. Section 4 provides an overview on the dataset and the empirical strategy, whose results are eventually presented in Section 5. Some robustness checks are presented in section 6 and finally, Section 7 concludes.

\section{Rice and minimum temperature}

In what follows, we report the results expounded in the natural science literature on the impact of minimum temperature on cereal production. Since minimum temperature is reached during the night, by smoothing the variations across the 24-hour temperature range, scholars might have failed to consider the actual transmission channels to conflict. The evidence is substantial in this respect. Dore (1959) suggested length of day and night and related change in temperature have an impact on rice flowering. We focus on evidence proposed about the impact of minimum temperature on rice crops. Sinha et al. (1991) estimate that in India and China the rice yield is severely dependent on total radiation and minimum temperature from flowering to ripening. In Indonesia, higher air temperatures increase the respiration rate of rice plants, reduce net photosynthesis, and eventually reduce plant yield. Amien et al. (1996), based on a forecasting model that predicts rice yield given climate change in Java, suggested that the observed slight increase in minimum temperature will significantly decreases the yield.

Wheeler et al. (2000) emphasize the impact of minimum temperature variations during the rice cropping seasons. They acknowledge that "research into the effect of high night temperature is not been understood well and should be prioritized with much higher mean night temperatures' predicted" (page 75). Higher minimum temperatures increase the maintenance respiration requirement of the crops and shorten the time to maturity, thus reducing net growth and productivity. Peng et al. (2004) find that also increased night-time temperatures 
associated with global warming cause rice yields to fall in Indonesia. Although this result holds for other south-eastern countries (e.g. Welch et al., 2010 provide estimates for the Philippines), Peng et al., (2004) have been criticized in those studies that focus on China (Huang et al., 2013; Deng et al., 2010; Zhang et al., 2010; You et al., 2009), where an increase in temperatures, especially minimum temperatures (Tao et al., 2008), increases rice yields. This apparent contradiction depends on the fact that climate warming may rise yield in cooler climates and lower them in warmer climate (Grant et al., 2011). The aggregate world effect in the period 1961-2002, as estimated by Lobell and Field (2007), is in fact negative but close to zero, given the different impact across countries. In a subsequent work, extending the dataset until 2008, Lobell et al. (2011) confirm that global warming reduces rice and soybeans production in Indonesia. ${ }^{6}$

Lal (2011) confirms the presence of such a biological mechanism in South Asia; there is also a direct evidence that rainfall and temperatures affect rice yields in Indonesia. Yet, rainfall is the most common variable exploited in empirical studies. Evidence of a negative correlation between sea surface temperature anomaly (SSTA) and rainfall has been provided by Naylor et al. (2007) in a study of Java and Bali, Deng et al. (2010) in China and Roberts et al., (2008) in the Philippines. Naylor et al. (2001) quantify the connections between El NiñoSouthern Oscillation (ENSO) indices, rainfall, and rice production for Java Indonesia's main rice-growing region. They find that El Niño causes drought, due to the deep atmospheric convection associated with the Indonesian low shifts eastward, and threatens rice production.

In sum, natural sciences clearly indicate to look at the minimum temperature, that is the air warmth reached during the night, as a crucial variable of rice crops.

\section{Sources, data and variables}

We use the UNSFIR dataset on social violence events, covering 14 provinces for the years 1990-2003.7 It provides detailed information about the date of any event, namely among others: the exact location, the degree of severity (number of killed

\footnotetext{
6 A similar apparent ambiguity is found in the study of wheat production: despite the negative correlation between global warming and yield in the world dataset (Lobell and Field, 2007; Lobell et al., 2011; Semenov, 2009), Nicholls (1997) reports that in Australia the increase in minimum temperatures reduces the likelihood of frosts, therefore increasing wheat yield.

${ }^{7}$ Data downloaded from www.conflictanddevelopment.org.
} 
and injured individuals), the involvement of the army, the material consequences of the event (arrested individuals, burned houses, shops and public buildings), and the source of the data. The data are drawn from 19 newspapers at the provincial level. The UNSFIR dataset records incidents of collective violence and listed communal, separatist, state-community and industrial relations violence. It focuses on a specific type of violence, i.e. 'group violence'. In particular, the dataset includes 3608 events of social violence. We have aggregated the violence data at the yearly level so obtaining $12 \times 14=168$ observations per province. We draw from this dataset two alternative dependent variables, in order to consider both the emergence and the severity of violence, namely: (1) the count of monthly events, labeled incidents; (2) the number of monthly victims (defined as the sum of injured and killed people), labeled severity. If we look at the territorial patterns of violence, all the provinces show decreasing levels of violence in the last years of the dataset, except for East Jawa (Jawa Timur) and Riau. Figure 1 reports the number of incidents and their severity. The figure shows that both share a similar pattern, and are unevenly distributed across time, peaking in the years around the transition and then decreasing (more sharply in the case of severity). We have aggregated the violence data at the monthly level so obtaining $12 \times 14=168$ observations per province.

Figure 1. Yearly frequency of violence

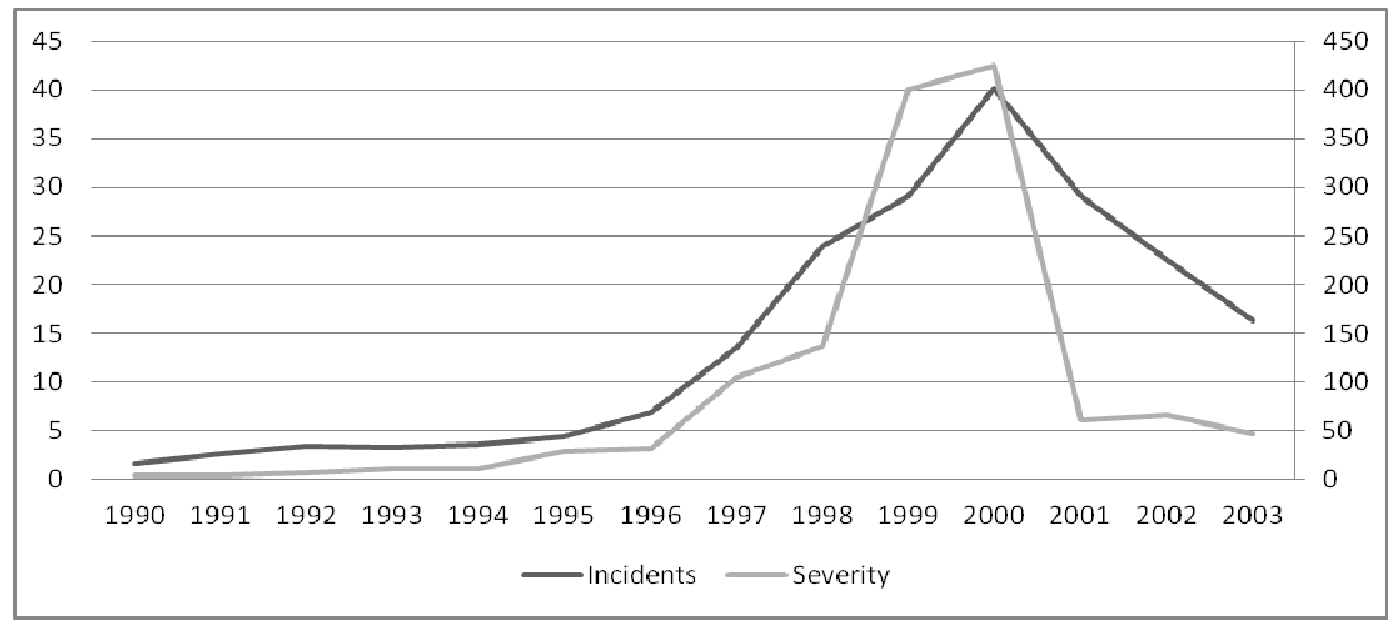

Note: own calculations from UNSFIR dataset. Left scale: incidents; right scale: severity 
We draw the climatic variables from NOAA's GHCN (Global Historical Climatology Network) -Daily, an integrated source of information from land surface stations. ${ }^{8}$ There are 17 climatic stations in Indonesia, which are widespread around the whole archipelago, covering a large area of the country. The map in figure 2 highlights the location of the stations. Only seven districts host a climatic station in their own territory. We therefore matched stations with provinces, by associating a province to the closest station on the map. Table 1 reports the matching.

Figure 2. Map of the NOAA-GHCN stations in Indonesia

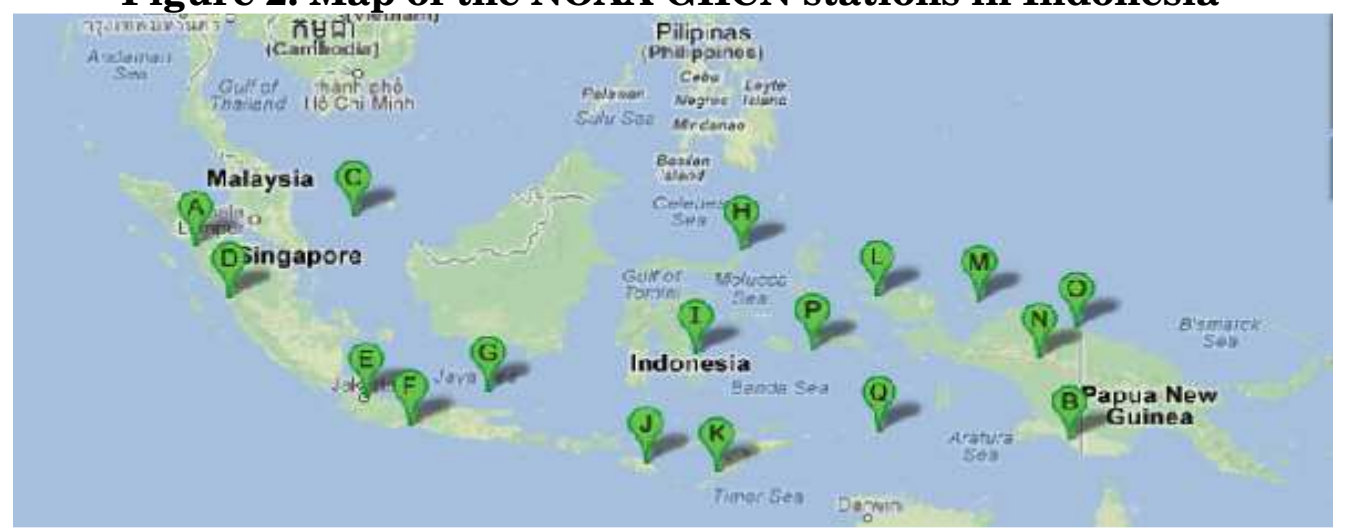

Note: Own elaboration from Google Maps

Table 1. Description of the climatic stations in Indonesia

\begin{tabular}{llc}
\hline Name of the station & Associated province & Reference on the map \\
\hline SIBOLGA/PINANGSORI & North Sumatra & $\mathrm{A}$ \\
TAREMPA & Riau & $\mathrm{C}$ \\
PADANG/TABING & West Sumatra & $\mathrm{D}$ \\
JAKARTA/OBSERVATORY & Jakarta (Special City District) & $\mathrm{E}$ \\
CILACAP & Central Jawa & $\mathrm{F}$ \\
SANGKAPURA (BAWEAN & East Jawa & $\mathrm{G}$ \\
MENADO/SAM RATULAN & North Sulawesi & $\mathrm{H}$ \\
KENDARI/WOLTER MONG & South-East Sulawesi & $\mathrm{I}$ \\
WAINGAPU/MAU HAU & East Nusa Tenggara & $\mathrm{J}$ \\
KUPANG/ELTARI & East Nusa Tenggara & $\mathrm{K}$ \\
SORONG/JEFMAN & West Papua & $\mathrm{L}$ \\
BIAK/FRANS KAISIEPO & Papua & $\mathrm{M}$ \\
WAMENA & West Papua & $\mathrm{N}$ \\
JAYAPURA/SENTANI & Papua & $\mathrm{O}$ \\
AMBON/PATTIMURA & Maluku & $\mathrm{P}$ \\
SAUMLAKI/OLILIT & Maluku & $\mathrm{P}$ \\
MERAUKE/MOPAH & Papua & $\mathrm{B}$ \\
\hline
\end{tabular}

\footnotetext{
${ }^{8}$ Data have been downloaded from: http://www.ncdc.noaa.gov/oa/climate/ghcn-daily/.
} 
The NOAA dataset includes detailed information on: (1) daily rainfall, in tenth of millimeters $(\mathrm{mm} / 10)$, denoted by rainfall; (2) minimum temperature in tenth of Celsius degrees $\left({ }^{\circ} \mathrm{C} / 10\right)$ (denoted by mintemp). Figures 3-4 provide climate patterns; in particular, they plot the deviation of observed rainfall and minimum temperature from the monthly average during the whole period. The minimum temperature jumps above the average from 1993 to 1996. The latest years of the dataset are characterized by another wave of winter warmth, of about $+0.9^{\circ} \mathrm{C}$ in TMIN. As an illustration, the months of October and November in 1992 were much rainier than the average of October and November since 1990 to 2003; the same months in 1997 were much less rainy than their average. Summing up, figure 4 indicates a reduction of rainfall in the latest years.

Figure 3. Monthly deviation of minimum temperature in Indonesia, 1990-2003

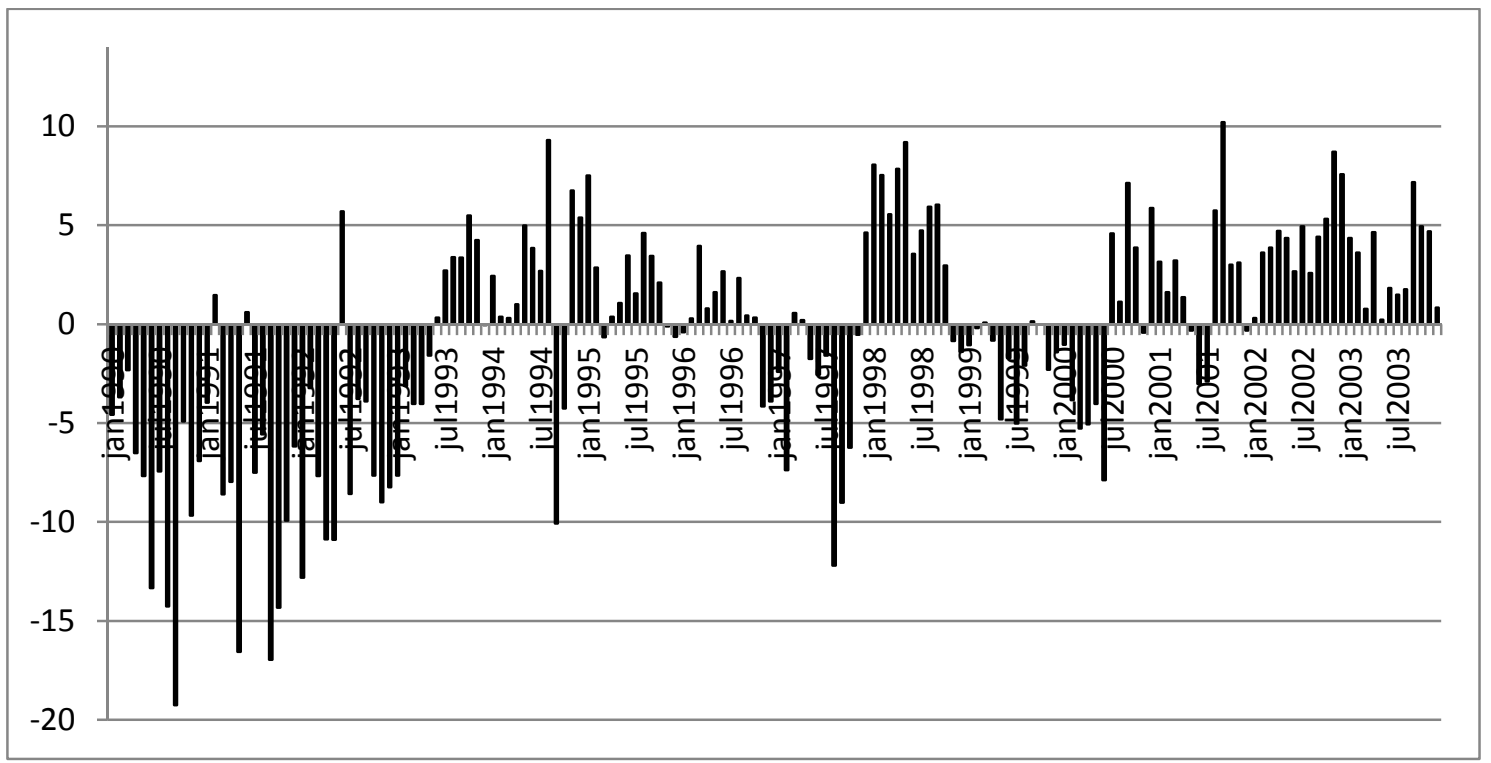

Note: Deviations in ${ }^{\circ} \mathrm{C} / 10$. Own elaboration from NOAA-GHCN data 
Figure 4. Monthly rainfall deviation in Indonesia, 1990-2003

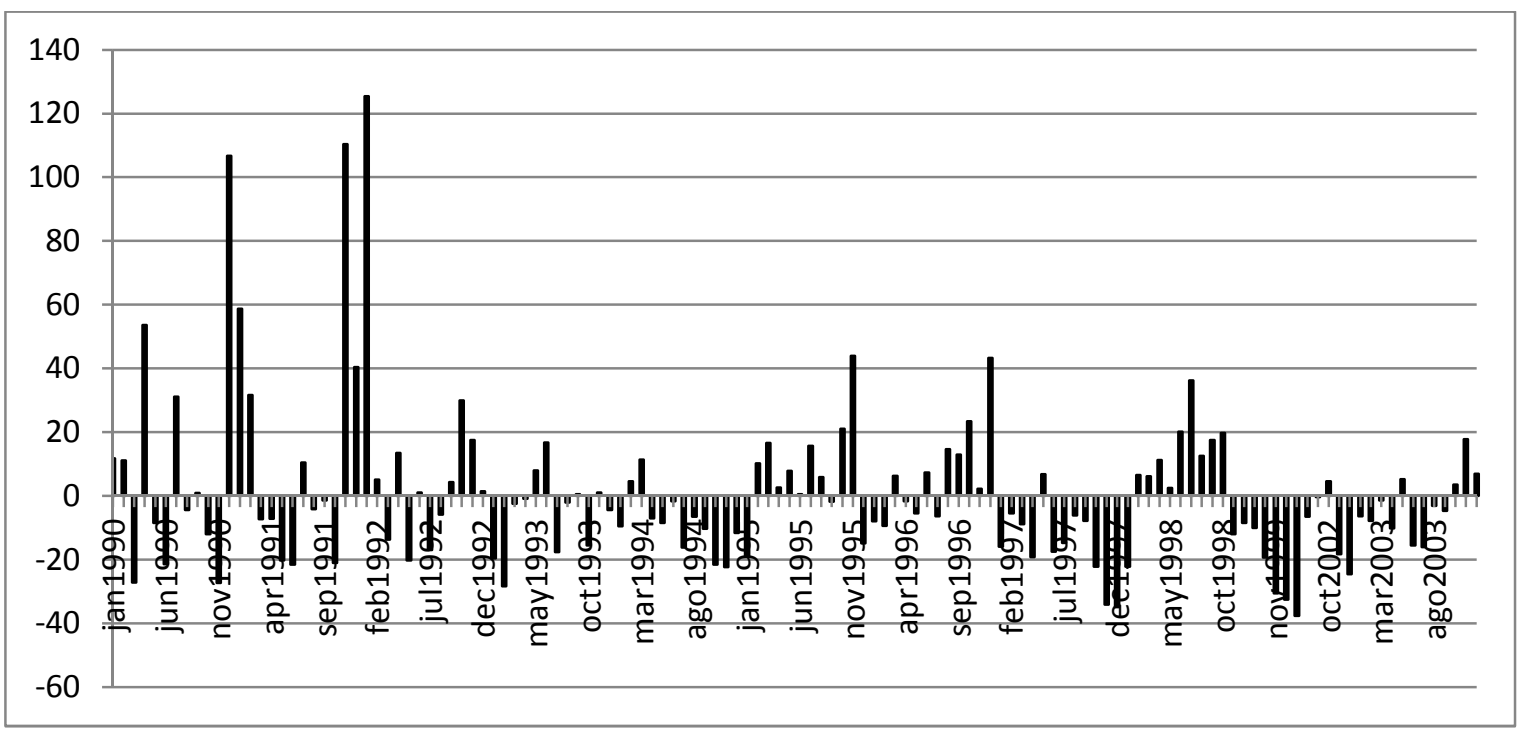

Note: Deviations in mm/10 rainfall. Own elaboration from NOAA-GHCN Daily data.

\section{The empirical specification}

We test whether emergence and severity of violence are associated with an indicator of food availability. As noted above, we use a IV model in which climate variables are used as instrument in the first stage. In particular, we use deviations in rainfall and minimum temperature as instruments. We estimate the following structural equation, by means of a negative binomial model:

violence $_{i t}=\beta_{0}+\beta_{1}$ paddy tonspc $i t+\beta_{2} X_{i t}+\mu_{i}+\theta_{t}+\varepsilon_{i t}$

where Violence $=$ (Incidents, Severity) denotes alternatively the dependent variables chosen, namely the count of violent incidents, or their severity. Dependent variables are count. In the light of the over-dispersion (see table 2), we rule out the Poisson model and use a Negative Binomial model. As noted above, Paddy tonspc measures the actual production of rice per capita and $X$ is a vector of socioeconomic variables.

The choice of covariates depends on the established literature and data availability. First we include the logged measure of population. A positive sign is expected to be associated to the variable Population. We capture the overall economic scenario through a measure of regional GDP. We also try to capture the degree of income inequality, by means of the Share of poor population. Following Murshed and 
Tadjoeddin (2008), we include a dummy variable for the decentralization reform, equal to 1 from 2001 onwards. This should capture the conflict-reducing effect of giving more power to local authorities. Finally, we included two variables that take into account living standards. They are labeled Improved water source and Share of area by household, respectively. The first is the share of households with access to improved sources of water, while the latter is the percentage of households by area of occupancy per capita at most equal to $7.2 \mathrm{~m}^{2}$. The first is expected to exhibit a negative association with violence whereas the latter can be expected to exhibit a positive one.

As noted above, we apply an IV approach to the Negative Binomial (NegBin) regression model. This type of estimation is technically problematic because the STATA command $x$ tnbreg, which estimates a panel NB model, does not allow for the introduction of instrumental variables. The 2SLS estimation, on the other hand, treats the dependent variable as a continuous one. We overcome this problem by estimating a GLM model that accounts for the binomial distribution of the dependent variables, using the qvf command as in Hardin and Schmiediche (2003). ${ }^{9}$ This procedure is the best suited to estimate our model; we verified the consistency of our argument in a set of preliminary regressions, using both 2SLS and IV-NB. The coefficients associated to the independent variables show the same sign across the models, but they gain statistical significance when moving from the IV to the IV-NB model, as expected. ${ }^{10}$ The unique limitation of this approach is its conciseness, as it does not provide neither the first stage regression results, nor the diagnostic tests. In addition, the coefficients are not generally interpretable.

With regard to the choice of instruments, we selected them by looking at the rice calendar (figure 5). There are two planting seasons in Indonesia, the 'wet season', and the 'dry season' (see Naylor et al., 2001; Falcon et al., 2004; Skoufias et al., 2012).

\footnotetext{
${ }^{9}$ Recent applications are in Dube and Vargas (2013) and Ritter and Conrad (2012).

10 These results have not been included in the text for sake of simplicity; nonetheless, they are available upon request.
} 
Tabella 2. Descriptive Statistics

\begin{tabular}{|c|c|c|c|c|c|c|c|}
\hline Variable & Description & Source & Obs & Mean & Std. Dev. & Min & $\operatorname{Max}$ \\
\hline Incidents & Number of events of social violence per year & $\begin{array}{l}\text { Author's } \\
\text { calculations } \\
\text { from NOAA }\end{array}$ & 252 & 14.32 & 27.89 & 0 & 189 \\
\hline Severity & $\begin{array}{l}\text { Number of victims (killed and injured) by } \\
\text { conflict }\end{array}$ & & 252 & 95.39 & 346.18 & 0 & 3995 \\
\hline$\Delta \operatorname{mintemp} p_{t-1}$ & $\begin{array}{l}\text { Deviation of the minimum temperature } \\
\text { during the past December, }{ }^{\circ} \mathrm{C}^{*} 10\end{array}$ & & 189 & -0.07 & 10.658 & -75.578 & 25.922 \\
\hline$\Delta d e c_{-} r a i n_{t-1}$ & $\begin{array}{l}\text { Deviation of the rainfall during the past } \\
\text { December, } \mathrm{mm}^{*} 10\end{array}$ & & 156 & -0.719 & 70.147 & -52.97 & 478.03 \\
\hline \multirow[t]{2}{*}{$\begin{array}{l}\text { Population } \\
\text { Regional GDP }\end{array}$} & Regional population & BPS & 2,784 & $8,952,406$ & $11,700,000$ & 785,059 & $39,200,000$ \\
\hline & Regional GDP(per thousand inhabitants) & & 2,208 & $1,415.99$ & $8,251.67$ & 60.44 & $75,114.21$ \\
\hline Improved water source & $\begin{array}{l}\text { Regional share of Households by access } \\
\text { to sources of improved drinking water } \\
\text { Percentage of Households by Province and }\end{array}$ & & $\begin{array}{l}2,172 \\
2,172\end{array}$ & $\begin{array}{l}42.08 \\
42.08\end{array}$ & $\begin{array}{l}9.89 \\
9.89\end{array}$ & $\begin{array}{l}20.13 \\
20.13\end{array}$ & $\begin{array}{l}81.69 \\
81.69\end{array}$ \\
\hline$\%$ of Households by area & $\begin{array}{l}\text { Area of Occupancy per capita }<=7.2 \mathrm{~m} 2 \\
\text { Log of Paddy production per capita (in }\end{array}$ & & 2,172 & 18.83 & 9.49 & 3.44 & 45.01 \\
\hline paddy tonspc & Tons) & & 184 & 0.294 & 0.418 & 0 & 2.091 \\
\hline $\begin{array}{l}2001 \text { Dummy } \\
\text { Share of poor }\end{array}$ & $\begin{array}{l}\text { Dummy for Decentralization reform from } \\
2001 \text { onwards } \\
\text { Regional share of population below the } \\
\text { poverty threshold }\end{array}$ & $\begin{array}{l}\text { Mursheb and } \\
\text { Taodjeddin, } 2008 \\
\text { Mursheb and } \\
\text { Taodjeddin, 2007 }\end{array}$ & 214 & 0.214 & 0.411 & 2.35 & 48. \\
\hline
\end{tabular}


Figure 5. The crop year

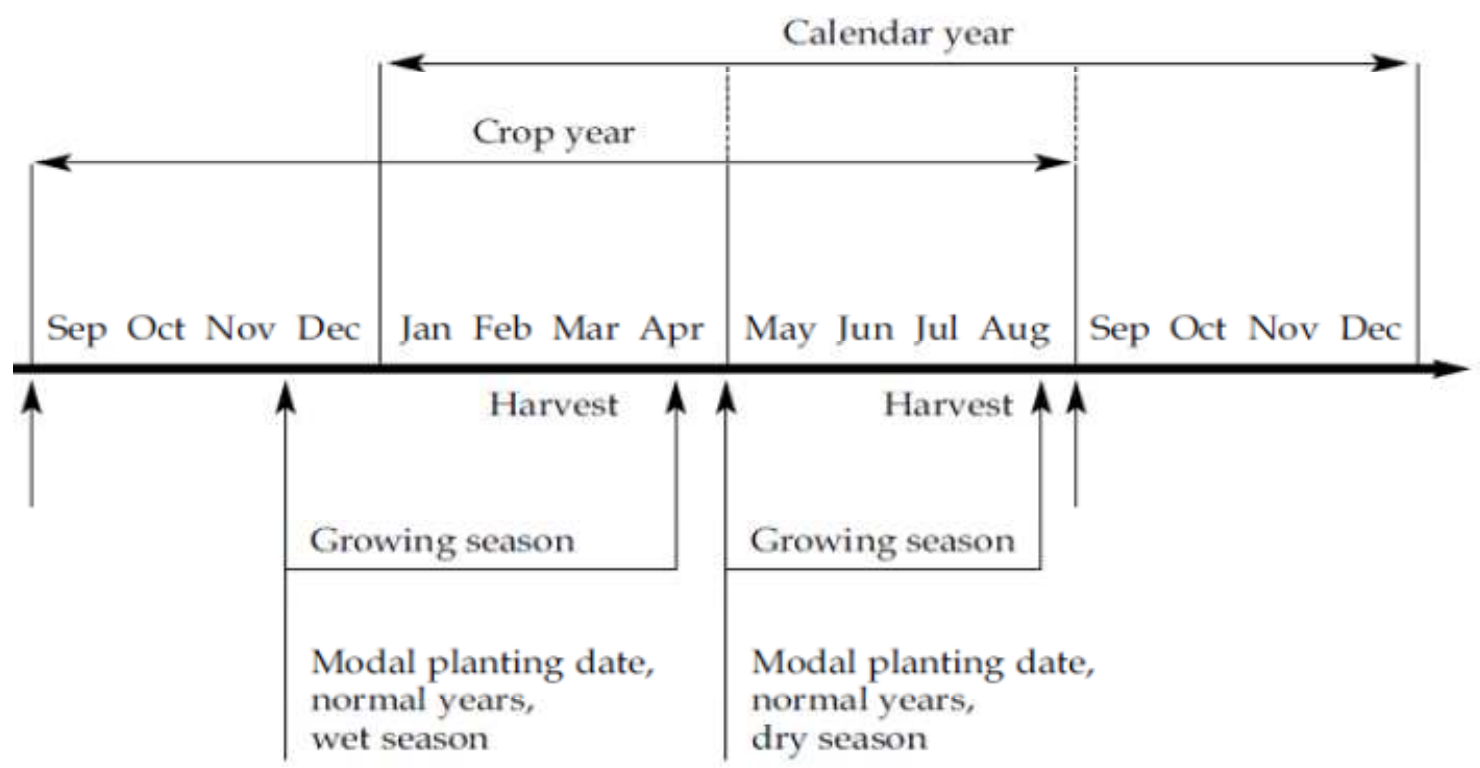

Source: Falcon et al. (2004)

The calendar begins with the monsoon onset in August, necessary for land preparation. This stage involves plowing and harrowing to "till" or dig-up, mix, and overturn the soil, and leveling it. ${ }^{11}$ Pre-germinated seedlings are grown in a seedbed, waiting for being transplanted to the wet field. The main seeding occurs from October to December, the core of the 'wet season'; in 60-120 days the sprouts reach maturation. Finally, from January to March the rice is harvested. Between the planting and the harvest there is a period called 'paceklek', characterized by an increase in the rice prices. If a shock occurs during the wet season, the crop is negatively affected, e.g. if the temperature rises, the monsoon is delayed and the plants lack water. A shift onwards in the calendar of the wet season generates an extension of the 'paceklek', with dramatic economic consequences over both consumers and producers. If no shocks occur, the 'dry' growing season starts in April, and the harvest is expected in June. The timing of this second, smaller planting season is entirely dependent on the performance of the wet season.

Based on these considerations, we use the deviation of both rainfall and minimum temperature during the wet season as instruments for the current year's rice production. As the rice calendar showed, the core of the growing period is represented by the last three months of the year, and if a shock occurs at this stage

11 Source: International Rice Research Institute, IRRI. Link: http:/ / irri.org / 
of the process, future crops are severely affected. Specifically the instruments, labeled $\Delta$ dec_rain $_{t-1}$ and $\Delta$ mintemp $_{t-1}$, indicate how much the past December has been more or less rainy, and warmer or colder, when compared to the average December in the period 1990-2003.

We use deviations recorded in December because the climatic variations during the wet season are correlated among themselves, therefore we have selected the ending month of the season as the most representative: if a shock occurs in December, there is no time for delays, and the crop is irreparably affected. ${ }^{12}$ The reduced form of equation (1) is:

Paddy tonspc $_{t}=f\left(\Delta\right.$ dec_rain $_{t-1}, \Delta$ mintemp $\left._{t-1}, X_{i t}\right)$

The correlation between the past December variation of the minimum temperature and rice production per capita is negative and significant as expected (corr: -0.16 , $\mathrm{p}$-value 0.04$)$. In contrast, the pairwise correlation between $\Delta$ mintemp $p_{t-1}$ and the dependent variable does not show this feature. ${ }^{13}$ This rough evidence rules out $a$ priori the doubts about the weakness of the instruments. ${ }^{14}$

\section{Results}

This section presents the results of structural equation (1). We estimate a negative binomial model with fixed effects to account for unobserved heterogeneity due to unit (province) specificity; all the specifications include year dummies that have been omitted in the presentation of the results. Results clearly show a negative and significant association between measures of violence and paddy production per capita. Put differently for the sake of simplicity, whenever food availability increased violence decreased. Whenever significant, control variables exhibit the expected signs. Population is always positive, and land pressure (proxied by

\footnotetext{
12 Deviation of the minimum temperature during the past December: Corr (Dec, Nov) $=-0.260 *$; Corr $($ Nov, Oct $)=0.851^{*}$; Corr (Oct, Sept): $0.888^{*}$; Deviation of rainfall during the past December: Corr $($ Dec, Nov $)=0.515^{*}$; Corr $($ Nov, Oct $)=0.467 *$; Corr (Oct, Sept): $0.647^{*}$.

13 Pairwise correlation: Corr $\left(\Delta D e c \_r a i n t-1, \Delta\right.$ Incidents $\left._{t-1}\right):-0.14, p$-value 0.08 ; Corr $\left(\Delta D e c \_r a i n t-1\right.$,

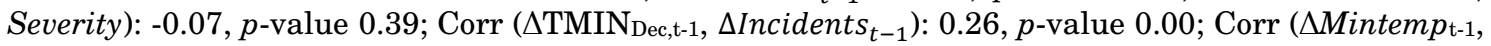
Severity): $-0.06, p$-value 0.38 .

14 Further robustness checks and the results of the diagnostics test for the fit of the instruments are provided in section 6 .
} 
percentage of households by area of occupancy per capita at most equal to $7.2 \mathrm{~m}^{2}$ ) seems to increase the number of violent incidents (see model 4). ${ }^{15}$

Table 3. Violence and Rice production per capita, IV-NB

\begin{tabular}{|c|c|c|c|c|c|c|c|c|}
\hline & 3.1 & 3.2 & 3.3 & 3.4 & 3.5 & 3.6 & 3.7 & 3.8 \\
\hline & \multicolumn{4}{|c|}{ Dep.var. Incidents } & \multicolumn{4}{|c|}{ Dep.var. Severity } \\
\hline $\begin{array}{l}\text { Paddy tons } \\
\text { per capita }\end{array}$ & $\begin{array}{l}-1.349^{*} \\
(0.769)\end{array}$ & $\begin{array}{l}-1.38^{* *} \\
(0.619)\end{array}$ & $\begin{array}{c}-1.496^{* *} \\
(0.734)\end{array}$ & $\begin{array}{c}-1.237 * * * \\
(0.472)\end{array}$ & $\begin{array}{l}-2.17^{*} \\
(1.302)\end{array}$ & $\begin{array}{l}-1.995^{*} \\
(1.139)\end{array}$ & $\begin{array}{l}-2.069^{*} \\
(1.138)\end{array}$ & $\begin{array}{c}-1.733^{* *} \\
(0.864)\end{array}$ \\
\hline $\begin{array}{l}\text { Population } \\
\text { (ln) }\end{array}$ & $\begin{array}{c}1.112^{* * * *} \\
(0.227)\end{array}$ & $\begin{array}{l}1.34 * * * \\
(0.232)\end{array}$ & $\begin{array}{c}1.889^{* * * *} \\
(0.614)\end{array}$ & $\begin{array}{c}2.053 * * \\
(0.536)\end{array}$ & $\begin{array}{c}0.315 \\
(0.429)\end{array}$ & $\begin{array}{l}0.391 \\
(0.46)\end{array}$ & $\begin{array}{c}0.463 \\
(0.875)\end{array}$ & $\begin{array}{c}0.639 \\
(0.787)\end{array}$ \\
\hline $\begin{array}{l}\text { Regional } \\
\text { GDP }\end{array}$ & $\begin{array}{l}-0.282 \\
(0.335)\end{array}$ & $\begin{array}{c}-0.278 \\
(0.281)\end{array}$ & $\begin{array}{l}-0.0152 \\
(0.371)\end{array}$ & $\begin{array}{c}0.055 \\
(0.306)\end{array}$ & $\begin{array}{l}-0.391 \\
(0.618)\end{array}$ & $\begin{array}{c}-0.36 \\
(0.537)\end{array}$ & $\begin{array}{l}-0.523 \\
(0.511)\end{array}$ & $\begin{array}{c}-0.314 \\
(0.435)\end{array}$ \\
\hline $\begin{array}{l}\text { Share of poor } \\
\text { population }\end{array}$ & & $\begin{array}{l}0.031 \\
(0.02)\end{array}$ & & $\begin{array}{c}0.007 \\
(0.025)\end{array}$ & & $\begin{array}{c}0.003 \\
(0.034)\end{array}$ & & $\begin{array}{l}-0.022 \\
(0.039)\end{array}$ \\
\hline $\begin{array}{l}\text { Share of area } \\
\text { by household }\end{array}$ & & & $\begin{array}{c}0.106 \\
(0.067)\end{array}$ & $\begin{array}{l}0.106^{*} \\
(0.055)\end{array}$ & & & $\begin{array}{c}0.062 \\
(0.087)\end{array}$ & $\begin{array}{c}0.057 \\
(0.069)\end{array}$ \\
\hline $\begin{array}{l}\text { Improved } \\
\text { water source }\end{array}$ & & & $\begin{array}{l}-0.019 \\
(0.039)\end{array}$ & $\begin{array}{l}-0.014 \\
(0.039)\end{array}$ & & & $\begin{array}{c}0.036 \\
(0.065)\end{array}$ & $\begin{array}{c}0.028 \\
(0.065)\end{array}$ \\
\hline 2001 dummy & $\begin{array}{c}1.163 \\
(1.737)\end{array}$ & $\begin{array}{c}0.822 \\
(1.569)\end{array}$ & $\begin{array}{c}0.619 \\
(1.602)\end{array}$ & $\begin{array}{c}0.166 \\
(1.311)\end{array}$ & $\begin{array}{c}0.695 \\
(2.994)\end{array}$ & $\begin{array}{c}0.489 \\
(2.785)\end{array}$ & $\begin{array}{c}1.499 \\
(2.253)\end{array}$ & $\begin{array}{c}0.649 \\
(1.865)\end{array}$ \\
\hline Constant & $\begin{array}{c}-18.62^{* * *} \\
(2.821) \\
\end{array}$ & $\begin{array}{c}-23.06^{* * * *} \\
(3.684) \\
\end{array}$ & $\begin{array}{c}-31.32^{* * * *} \\
(9.624) \\
\end{array}$ & $\begin{array}{c}-33.68^{* * * *} \\
(8.203) \\
\end{array}$ & $\begin{array}{c}-5.62 \\
(6.189) \\
\end{array}$ & $\begin{array}{c}-6.50 \\
(6.877) \\
\end{array}$ & $\begin{array}{c}-10.94 \\
(13.931) \\
\end{array}$ & $\begin{array}{c}-11.52 \\
(11.459) \\
\end{array}$ \\
\hline Observations & 108 & 108 & 108 & 108 & & & 108 & 108 \\
\hline
\end{tabular}

Notes: instruments: a) monthly deviation of the minimum temperature (December t-1); b) monthly deviation of the rainfall (December $\mathrm{t}-1$ ); Standard errors in parentheses; *** $\mathrm{p}<0.01, * * \mathrm{p}<0.05, *$, $\mathrm{p}<0.1$

As noted above, the GLM estimator does not provide neither the first stage regression results, nor the diagnostic tests. Yet, we are not able to provide the magnitude of the estimates because the coefficients are not punctually interpretable. ${ }^{16}$ Anyway, a comparison of the coefficients for emergence and

15 These results are robust to the use of the harvested area (Paddy area), as expected. In fact, the correlation between paddy tons and harvested area is positive, significant and very high (0.98, p-value: 0.000$)$. tests are not disclosed, They are available upon request.

${ }_{16}$ As matter of comparison, we have estimated a benchmark set of regressions using 2SLS to get diagnostics and benchmark coefficients, and compared them with those presented in table 3 . The introduction of the instruments in a $2 S L S$ framework corrects the sign of the relationship, but it still treats the number of events as a continuous variable that might take also negative values, affecting the standard errors. From a methodological perspective the $N B$ model is best suited, and we find it to be also the best fitting one. Since the coefficient are the same, but as expected they gain significance in the IV NB model, we do not report the IV 2SLS coefficients but we report in Table 4 the first stage regressions. In fact, we computed the diagnostic tests for IV-OLS, i.e. Kleibergen-Paap LM statistic and the Hansen $J$, which test respectively underestimation and overestimation. For the correct identification of the model, the coefficient associated to the Kleibergen-Paap LM statistic must be 
severity of violence suggests that superior food availability explains more effectively a decrease in severity of violence. Stated differently, the current number of monthly victims (defined as the sum of injured and killed people) decreases with respect to the value of the paddy production per capita. This sheds light on the causal mechanism between climate variables and violence in Indonesia. If minimum temperature in the previous December increases, paddy rice per capita decreases. This implies lower food availability so inflaming violence.

\section{Robustness}

In what follows we present some robustness tests to either validate or contrast our methodology and results. First, we follow the Hsiang et al., 2013 by considering non-linearities in the relationship between climate variables and violence.

Table 4. Violence and Rice production per capita IV-NB; non linearities: instruments in quadratic form

\begin{tabular}{|c|c|c|c|c|c|c|c|c|}
\hline & 4.1 & 4.2 & 4.3 & 4.4 & 4.5 & 4.6 & 4.7 & 4.8 \\
\hline & \multicolumn{4}{|c|}{ Dep.var.: Incidents } & \multicolumn{4}{|c|}{ Dep.var.: Severity } \\
\hline $\begin{array}{l}\text { Paddy tons } \\
\text { per capita }\end{array}$ & $\begin{array}{l}-1.292^{*} \\
(0.741)\end{array}$ & $\begin{array}{l}-1.305^{* *} \\
(0.527)\end{array}$ & $\begin{array}{l}-1.368^{* *} \\
(0.692)\end{array}$ & $\begin{array}{l}-1.037 * * \\
(0.420)\end{array}$ & $\begin{array}{l}-2.695^{* *} \\
(1.128)\end{array}$ & $\begin{array}{l}-1.985^{* *} \\
(0.792)\end{array}$ & $\begin{array}{l}-2.712^{* *} \\
(1.081)\end{array}$ & $\begin{array}{l}-1.712^{* *} \\
(0.721)\end{array}$ \\
\hline Population (ln) & $\begin{array}{l}1.103^{* * * *} \\
(0.226)\end{array}$ & $\begin{array}{l}1.321^{* * *} \\
(0.237)\end{array}$ & $\begin{array}{l}1.793^{* * *} \\
(0.562)\end{array}$ & $\begin{array}{l}1.912^{* * * *} \\
(0.476)\end{array}$ & $\begin{array}{l}0.168 \\
(0.507)\end{array}$ & $\begin{array}{l}0.248 \\
(0.429)\end{array}$ & $\begin{array}{l}0.657 \\
(1.011)\end{array}$ & $\begin{array}{l}0.573 \\
(0.723)\end{array}$ \\
\hline Regional GDP & $\begin{array}{l}-0.258 \\
(0.295)\end{array}$ & $\begin{array}{l}-0.267 \\
(0.260)\end{array}$ & $\begin{array}{l}0.003 \\
(0.335)\end{array}$ & $\begin{array}{l}0.046 \\
(0.277)\end{array}$ & $\begin{array}{l}-0.637 \\
(0.558)\end{array}$ & $\begin{array}{l}-0.462 \\
(0.410)\end{array}$ & $\begin{array}{l}-0.571 \\
(0.644)\end{array}$ & $\begin{array}{l}-0.315 \\
(0.425)\end{array}$ \\
\hline $\begin{array}{l}\text { Share of poor } \\
\text { population }\end{array}$ & & $\begin{array}{l}0.033^{*} \\
(0.019)\end{array}$ & & $\begin{array}{l}0.015 \\
(0.019)\end{array}$ & & $\begin{array}{l}0.005 \\
(0.027)\end{array}$ & & $\begin{array}{l}-0.019 \\
(0.028)\end{array}$ \\
\hline $\begin{array}{l}\text { Improved } \\
\text { water source }\end{array}$ & & & $\begin{array}{l}-0.016 \\
(0.035)\end{array}$ & $\begin{array}{l}-0.010 \\
(0.035)\end{array}$ & & & $\begin{array}{l}0.009 \\
(0.067)\end{array}$ & $\begin{array}{l}0.014 \\
(0.056)\end{array}$ \\
\hline $\begin{array}{l}\text { Share of area } \\
\text { by household }\end{array}$ & & & $\begin{array}{l}0.094 \\
(0.059)\end{array}$ & $\begin{array}{l}0.089 * \\
(0.049)\end{array}$ & & & $\begin{array}{l}0.084 \\
(0.090)\end{array}$ & $\begin{array}{l}0.046 \\
(0.064)\end{array}$ \\
\hline 2001 dummy & $\begin{array}{l}1.131 \\
(1.605)\end{array}$ & $\begin{array}{l}0.889 \\
(1.609)\end{array}$ & $\begin{array}{l}0.541 \\
(1.490)\end{array}$ & $\begin{array}{l}0.208 \\
(1.349)\end{array}$ & $\begin{array}{l}2.081 \\
(2.786)\end{array}$ & $\begin{array}{l}1.199 \\
(2.338)\end{array}$ & $\begin{array}{l}2.356 \\
(2.815)\end{array}$ & $\begin{array}{l}1.093 \\
(2.144)\end{array}$ \\
\hline Constant & $\begin{array}{l}-18.278^{* * *} \\
(3.012)\end{array}$ & $\begin{array}{l}-22.64 * * * \\
(3.867) \\
\end{array}$ & $\begin{array}{l}-29.393^{* * *} \\
(8.643)\end{array}$ & $\begin{array}{l}-31.172^{* * *} \\
(7.457)\end{array}$ & $\begin{array}{l}-5.258 \\
(7.971) \\
\end{array}$ & $\begin{array}{l}-4.721 \\
(7.516) \\
\end{array}$ & $\begin{array}{l}-14.787 \\
(15.08) \\
\end{array}$ & $\begin{array}{l}-9.823 \\
(10.94) \\
\end{array}$ \\
\hline Observations & 108 & 108 & 108 & 108 & 108 & 108 & 108 & 108 \\
\hline
\end{tabular}

Notes: instruments: a) monthly deviation of the minimum temperature (December t-1); b) monthly deviation of the rainfall (December t-1); c) a)^2; d) b) ${ }^{\wedge} 2$. Standard errors in parentheses; *** $p<0.01$, $* * \mathrm{p}<0.05, *, \mathrm{p}<0.1$

statistically significant while the Hansen $J$ coefficient not. As we read from the table, only the most complete specifications of the empirical model meet these requirements. 
We re-estimated equation (1) by including also the climatic variables in quadratic form within the instrument set. Results of the baseline estimation are confirmed. In addition, coefficients seem to gain significance. In particular, as noted in table 3, among dependent variables severity of violence appears to be more sensitive to non-linearities.

We also explore the possibility of interaction between instruments, since the combined effect of increasing temperature and rainfall may turn out to be significant. Therefore, we use as additional instrument the interaction between the monthly deviation of the minimum temperature recorded in past December and the monthly deviation of the rainfall, namely $\operatorname{smintemp}_{t-1} \times \Delta$ dec_rain $_{t-1}$. General results (see table 5) are confirmed. There is a significant negative association between rice production per capita and both emergence and severity of violence.

Table 5. Violence and Rice production per capita IV-NB;

interaction between the instruments

\begin{tabular}{|c|c|c|c|c|c|c|c|}
\hline & 5.1 & 5.2 & 5.3 & 5.4 & 5.5 & 5.6 & 5.7 \\
\hline & \multicolumn{4}{|c|}{ Dep.var.: Incidents } & \multicolumn{3}{|c|}{ Dep.var.: Severity } \\
\hline \multirow[t]{2}{*}{ Paddy tons per capita } & $-1.344^{*}$ & $-1.353^{* *}$ & $-1.482^{* *}$ & $-1.239 * * *$ & -1.793 & -1.866 & $-1.815^{* *}$ \\
\hline & $(0.811)$ & $(0.632)$ & $(0.738)$ & $(0.449)$ & $(1.351)$ & $(1.209)$ & $(0.806)$ \\
\hline \multirow[t]{2}{*}{ Population (ln) } & $1.134 * * *$ & $1.351^{* * *}$ & $1.898 * * *$ & $2.044^{* * *}$ & 0.388 & 0.434 & 0.672 \\
\hline & $(0.221)$ & $(0.241)$ & $(0.615)$ & $(0.536)$ & $(0.401)$ & $(0.485)$ & $(0.797)$ \\
\hline \multirow[t]{2}{*}{ Regional GDP } & -0.27 & -0.263 & -0.007 & 0.049 & -0.234 & -0.297 & -0.314 \\
\hline & $(0.342)$ & $(0.284)$ & $(0.367)$ & $(0.31)$ & $(0.574)$ & $(0.553)$ & $(0.452)$ \\
\hline \multirow[t]{2}{*}{$\begin{array}{l}\text { Share of poor } \\
\text { population }\end{array}$} & & 0.031 & & 0.007 & & 0.005 & -0.025 \\
\hline & & $(0.02)$ & & $(0.024)$ & & $(0.811)$ & $(0.811)$ \\
\hline \multirow[t]{2}{*}{$\begin{array}{l}\text { Improved water } \\
\text { source }\end{array}$} & & & -0.019 & -0.015 & & & 0.021 \\
\hline & & & $(0.039)$ & $(0.039)$ & & & $(0.065)$ \\
\hline \multirow[t]{2}{*}{$\begin{array}{l}\text { Share of area by } \\
\text { household }\end{array}$} & & & 0.105 & $0.106^{*}$ & & & 0.062 \\
\hline & & & $(0.067)$ & $(0.054)$ & & & $(0.07)$ \\
\hline \multirow[t]{2}{*}{2001 dummy } & 1.035 & 0.722 & 0.519 & 0.267 & -0.065 & 0.151 & 0.869 \\
\hline & (1.721) & (1.592) & (1.587) & (1.391) & $(2.729)$ & $(2.838)$ & $(2.043)$ \\
\hline \multirow{2}{*}{ Constant } & $-18.9 * * *$ & $\begin{array}{c}- \\
2319 * * *\end{array}$ & $-31381 * * *$ & $-33541 * * *$ & -5.446 & -6.717 & -11947 \\
\hline & $(2.814)$ & $(3.805)$ & (9.615) & $(8.184)$ & (5.789) & (6.985) & (11.648) \\
\hline Observations & 108 & 108 & 108 & 108 & 108 & 108 & 108 \\
\hline
\end{tabular}

Notes: instruments: a) monthly deviation of the minimum temperature (December t-1); b) monthly deviation of the rainfall (December $\mathrm{t}-1$ ); c) interaction between a) and b). Standard errors in parentheses; *** $\mathrm{p}<0.01,{ }^{* *} \mathrm{p}<0.05,{ }^{*} \mathrm{p}<0.1$ 
Models (1-4) employing the emergence of violence as dependent variable do perform better than models (5-8) in which the dependent variable is the severity of violence. Interestingly, in model 4 the share of poor population turns to be significantly and positively associated to the emergence of violence.

\section{Concluding remarks}

This paper contributes to the growing literature on the nexus between climate variables and violence by focusing on Indonesia for the period 1990-2003. We explored how variations in minimum temperature - as suggested by natural science literature - affects rice crops. Paddy rice is the main crop of Indonesia and therefore its scarcity can be blamed for fuelling violence. We adopted an IV approach to uncover the impact of variations in minimum temperature on emergence of actual violence through the effect on food availability, captured by rice crops per capita. Results show that an increase of the minimum temperature during the core month of the 'wet planting season', (i.e. past December), determines an increase in violence fuelled by the reduction in future rice production per capita. Put differently, there is a significant negative association between food availability and violence. Results are robust to some robustness checks.

Needless to say, the works also suffers from some limitations and caveats. First, the number of observations and the lack of data. Matching the UNSFIR data with NOAA climatic data provides a small number of observations (slightly larger than one hundred). Moreover, the choice of covariates also suffers from lack of data at province level. The main result we would claim for this work is methodological. Under the assumption that climate change affects emergence of violence through the agricultural production, we have chosen to focus on specific characteristics of a dominant crop in a specific country, namely paddy rice in Indonesia. From natural science literature we have drawn that crucial to rice growing is the minimum temperature in a limited period of time (wet planting season, December). We modelled our estimation framework upon such evidence. We believe that the robust evidence descends from such punctuality in taking into account the agricultural specificities of paddy rice. Stated broadly, our work cautiously suggests that some inconclusive results in literature on the climate change/violence nexus could suffer from not considering specificities of different crops. Further research seems necessary to overcome these weaknesses and to provide a more effective picture. 


\section{References}

Amien, I., Rejekiningrum, P., Pramudia, A., and Susanti, E. (1996). Effects of interannual climate variability and climate change on rice yield in Java, Indonesia. Water, Air, and Soil Pollution, 92(1-2), 29-39.

Auffhammer, M., S.M. Hsiang, W. Schlenker, A.H. Sobel (2013). Using Weather Data and Climate Model Output in Economic Analyses of Climate Change. Review of Environmental Economics and Policy, 7(2), 1-18.

Bernauer T., Bohemelt T., Koubi V. (2012), Environmental changes and violent conflict, Enviromental Research Letters, vol. 7

Bordey, F. H., Launio, C. C., Quilang, E. J. P., Tolentino, C. M. A., \& Ogena, N. B. (2013). Linking climate change, rice yield, and migration: the Philippine experience. WorldFish (ICLARM) - Economy and Environment Program for Southeast Asia (EEPSEA), Philippines.

Buhaug, H. (2010). Climate not to blame for African civil wars. Proceedings of the National Academy of Sciences, 107(38), 16477-16482.

Buhaug, H., Gleditsch, N. P., and Theisen, O. M. (2013). Is climate change a driver of armed conflict? Climatic Change, 1-13.

Burke, M. B., Miguel, E., Satyanath, S., Dykema, J. A., and Lobell, D. B. (2009). Warming increases the risk of civil war in Africa. Proceedings of the National Academy of Sciences, 106(49), 20670-20674.

Ciccone A., (2011), Economic Shocks and Civil Conflict: A Comment, American Economic Journal: Applied Economics, vol.3, n.1, pp. 215-227

Deng, X., Huang J., Qiao F., Naylor R.L., Falcon W.P., Burke M., Rozelle S., Battisti D. (2010). Impacts of El Nino-Southern Oscillation events on China's rice production, Journal of Geographical Science, 20(1): 3-16.

Dore, J. (1959). Response of Rice to Small Differences in Length of Day, Nature $183,413-414$.

Dube O., Vargas J., (2013), Commodity Price Shocks and Civil Conflict: Evidence from Colombia, The Review of Economic Studies, vol. 80, n.4, pp.1384-1421.

Falcon, W. P., Naylor, R. L., Smith, W. L., Burke, M. B., \& McCullough, E. B. (2004). Using climate models to improve Indonesian food security. Bulletin of Indonesian Economic Studies, 40(3), 355-377. 
Fjelde, H., and von Uexkull, N. (2012). Climate triggers: Rainfall anomalies, vulnerability and communal conflict in sub-Saharan Africa. Political Geography.

Gleditsch, N. P. (2012). Whither the weather? Climate change and conflict. Journal of Peace Research, 49(1), 3-9.

Grant, R. F., Kimball, B. A., Conley, M. M., White, J. W.,Wall, G. W., Ottman, M. J. (2011). Controlled Warming Effects on Wheat Growth and Yield: Field Measurements and Modeling, Agronomy Journal 103: 1742-1754.

Hardin J.W., Schmiediche H., (2003), Instrumental variables, bootstrapping and generalized linear models, The Stata Journal, vol. 3, n.4, pp. 351-360.

Hendrix C.S., and Salehyan I. (2012). Climate change, rainfall, and social conflict in Africa, Journal of Peace Research 49: 35.

Hsiang, S.M., Burke, M., \& Miguel, E., (2013). Quantifying the influence of climate on human conflict. Science $341,1235367$.

Huang M., Zhang W., Jiang L., Zou Y. (2013). Impact of temperature changes on early-rice productivity in a subtropical environment of China, Field Crops Research, No. 146:10-15.

Keil, A., Zeller, M., Wida, A., Sanim, B., \& Birner, R. (2008). What determines farmers' resilience towards ENSO-related drought? An empirical assessment in Central Sulawesi, Indonesia. Climatic Change, 86(3-4), 291-307.

Koubi, V., Spilker, G., Böhmelt, T., \& Bernauer, T. (2013). Do natural resources matter for interstate and intrastate armed conflict? Journal of Peace Research, August, 1-17.

Lal, M. (2011). Implications of climate change in sustained agricultural productivity in South Asia. Regional Environmental Change, 11(1), 79-94.

Lobell, D. B., \& Field, C. B. (2007). Global scale climate-crop yield relationships and the impacts of recent warming. Environmental Research Letters, 2(1), 014002.

Lobell, D. B., Schlenker, W., and Costa-Roberts, J. (2011). Climate trends and global crop production since 1980. Science, 333(6042), 616-620.

McCulloch, N. (2008). Rice prices and poverty in Indonesia. Bulletin of Indonesian Economic Studies, 44(1), 45-64. 
Miguel, E., Satyanath, S., \& Sergenti, E. (2004). Economic shocks and civil conflict: An instrumental variables approach. Journal of political Economy, 112(4), 725-753.

Miguel E., Satyanath S., (2011), Re-examining Economic Shocks and Civil Conflict, American Economic Journal: Applied Economics, 3, 228-232.

Murshed M., Tadjoeddin M.Z. (2007), Socio-Economic Determinants of Everyday Violence in Indonesia: An Empirical Investigation of Javanese Districts, 1994 --2003", Journal of Peace Research 44: 689.

Murshed, M. and Tadjoeddin., Z. (2008), Is Fiscal Decentralization Conflict Abating? Routine Violence and District Level Government in Java, Indonesia, MICROCON Research Working Paper No. 7, Brighton: MICROCON.

Naylor, R. L., Battisti, D. S., Vimont, D. J., Falcon, W. P., and Burke, M. B. (2007). Assessing risks of climate variability and climate change for Indonesian rice agriculture. Proceedings of the National Academy of Sciences, 104(19), 77527757.

Naylor, R. L., Falcon W. P., Rochberg D. and Wada N. (2001). Using El Nino/Southern Oscillation climate data to predict rice production in Indonesia, Climatic Change 50: 255-265.

Nicholls, N. (1997). Increased Australian wheat yield due to recent climate trends. Nature, $38 \quad 7(6632), 484-485$.

Peng, S., Huang, J., Sheehy, J. E., Laza, R. C., Visperas, R. M., Zhong, X., Centeno G.S., Khush G.S. and Cassman, K. G. (2004). Rice yields decline with higher night temperature from global warming. Proceedings of the National Academy of Sciences of the United States of America, 101(27), 9971-9975.

Raleigh C.; L. Jordan; and I. Salehyan. (2008). Assessing the impact of climate change on migration and conflict. The Social Development Department. The World Bank Group, Washington, DC.

Raleigh, C., \& Urdal, H. (2013). Climate change demography environmental degradation and armed conflict. Environmental Change and Security Program Report, 13, 27-33.

Ritter, E., \& Conrad, C. (2012). Let the Rain Settle It: Estimating the Effect of Dissent on Repression. In APSA 2012 Annual Meeting Paper. 
Roberts, M.G., Dawe D., Falcon W.P. and Naylor R.L. (2008). El Nino-Southern Oscillation Impacts on Rice Production in Luzon, the Philippines, Journal of Applied Meteorology and Climatology, 48:1718-1724.

Scheffran, J., Brzoska, M., Kominek, J., Link, P., \& Schilling, J. (2012). Climate change and violent conflict. Science(Washington), 336(6083), 869-871.

Semenov, M. A. (2009). Impacts of climate change on wheat in England and Wales. Journal of the Royal Society Interface, 6(33), 343-350.

Sinha, S. K., and Swaminathan, M. S. (1991). Deforestation, climate change and sustainable nutrition security: A case study of India. Climatic Change, 19(12), 201-209.

Skoufias, E., Katayama, R. S., \& Essama-Nssah, B. (2012). Too little too late: welfare impacts of rainfall shocks in rural Indonesia. Bulletin of Indonesian Economic Studies, 48(3), 351-368.

Slettebak, R. T. (2012). Don't blame the weather! Climate-related natural disasters and civil conflict. Journal of Peace Research, 49(1), 163-176.

Tadjoeddin, M.Z. (2002). Anatomy of social violence in the context of transition: the case of Indonesia, 1990-2001, Politics Administration and Change, 38:1-35.

Tadjoeddin, M.Z., Murshed S.M., (2007), Socio-Economic Determinants of Everyday Violence in Indonesia: An Empirical Investigation of Javanese Districts, 1994-2003, Journal of Peace Research, vol.44, no. 6, pp.689-709.

Tao F., Yokozawa M., Liu J., and Zhang Z. (2008). Climate-crop yield relationships at provincial scales in China and the impacts of recent climate trends, Climate Research, 38(1), pp-83-94.

Tol, R. S., \& Wagner, S. (2010). Climate change and violent conflict in Europe over the last millennium. Climatic Change, 99(1-2), 65-79.

Varshney, A., Panggabean, R. and Tadjoeddin, M.Z. (2004). Patterns of Collective Violence in Indonesia (1990-2003), UNSFIR Working Paper 04 / 03.

Welch, J. R., Vincent, J. R., Auffhammer, M., Moya, P. F., Dobermann, A., and Dawe, D. (2010). Rice yields in tropical/subtropical Asia exhibit large but opposing sensitivities to minimum and maximum temperatures. Proceedings of the National Academy of Sciences, 107(33), 14562-14567.

Wheeler T.R., Craufurd P.Q., Ellis R.H., Porter J.R., and Prasad P.V.V. (2000). Temperature variability and the yield of annual crops. Agric Ecosyst Environ 82(1-3):159-167. 
World Bank Conflict and Development Program (2010). New patterns of violence in Indonesia: preliminary evidence from six 'high-conflict' provinces, http: / / reliefweb.int/report/indonesia / new-patterns-violence-indonesiapreliminary-evidence-six-high-conflict-provinces.

You, L., Rosegrant, M. W., Wood, S., and Sun, D. (2009). Impact of growing season temperature on wheat productivity in China. Agricultural and Forest Meteorology, 149(6), 1009-1014.

Zhang, T., Zhu, J., and Wassmann, R. (2010). Responses of rice yields to recent climate change in China: an empirical assessment based on long-term observations at different spatial scales (1981-2005). Agricultural and Forest Meteorology, 150(7), 1128-1137. 